\title{
Navigating Horizon 2020 Funding
}

\author{
Christina Miller \\ UK Research Office \\ Rue du Trône 4, Brussels, Belgium \\ Christina.Miller@bbsrc.ac.uk
}

\section{EU FUNDING FOR RESEARCH AND INNOVATION}

Horizon 2020 is the principal European funding programme for research and innovation. This seven year programme with a budget of almost $€ 80$ billion will run until 2020. It is successor to the Seventh Framework Programme for Research and Technological Development (FP7).

\section{HOW TO NAVIGATE HORIZON 2020}

For someone new to European Funding, Horizon 2020 may appear a bit daunting. This presentation will describe the different types of opportunities available under each of the three main pillars 'Excellent Science', 'Industrial Leadership' and the 'Societal Challenges' and the principal funding streams.

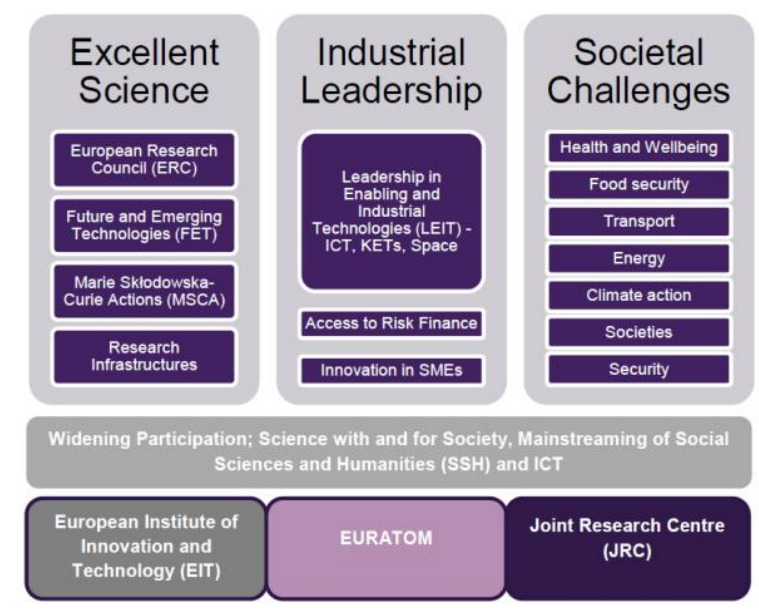

Figure 1: Simplified Horizon 2020 Structure (Diagram design by UK Research Office 2014)

Delegates will learn more about the evaluation and submission process, tips on building a consortia and preparing winning proposals. Understanding the policy context is vitally important for anyone applying to Horizon 2020, so this presentation will cover the key elements all applicants need to consider when applying for funding or deciding if a particular scheme is suitable.

Often researchers are put off by the perceived complexity of the programme and its rules. Delegates will learn the basics about the funding mechanism (and rates) and key pointers for managing Horizon 2020 projects.

\subsection{Finding the right opportunity for you}

With so many different ways to engage with Horizon 2020, this session aims to provide delegates with a starting point to match up their interests with suitable opportunities. For those already with experience in EU programmes it will help highlight areas that might not have been previously considered.

Horizon 2020 is designed as a programme to provide added value on top of national programmes. The size and scale of the opportunities are often much larger, and longer than those found nationally and are based in the most part on pan-EU collaborations.

Table 1: Horizon 2020 funds large scale, often pan-EU Research and Innovation projects

\begin{tabular}{|c|c|}
\hline $\begin{array}{c}\text { Yes, Horizon } 2020 \text { will } \\
\text { fund: }\end{array}$ & $\frac{\text { No, Horizon } 2020 \text { does }}{\text { not fund: }}$ \\
\hline $\begin{array}{l}\text { Multi-sector consortia } \\
\text { to solve topics under } \\
\text { societal challenges }\end{array}$ & $\begin{array}{l}\text { Occasional travel for } \\
\text { research meetings }\end{array}$ \\
\hline $\begin{array}{l}\text { European Research } \\
\text { Council Grants }\end{array}$ & $\begin{array}{l}\text { Smaller stand-alone } \\
\text { conferences or } \\
\text { workshops }\end{array}$ \\
\hline$\checkmark \quad$ Mobility programmes & \\
\hline
\end{tabular}

The Research Participant Portal is a good place to start for new comers to find out more about the open calls for proposals, register as an evaluator and find out more about the funded projects. 
Delegates will be guided through the various information sources and support available from National Contact Points.

The presentation will provide insight into the reasons why researchers apply for EU funding beyond the money. Delegates will learn from best practice on developing a strategic approach to European Funding and successful engagement.

\section{REFERENCES}

European Commission (2014) Horizon 2020 in brief: The EU Framework Programme for Research \& Innovation.

http://ec.europa.eu/programmes/horizon2020/en/ne ws/horizon-2020-brief-eu-framework-programmeresearch-innovation (retrieved 27 May 2015).

European Commission (2014) Research \& Innovation: Participant Portal.

http://ec.europa.eu/research/participants/portal/des ktop/en/home.html (retrieved 27 May 2015). 